\title{
Corporate Social Responsibility Research- Bibliometric Insight
}

Ag Kaifah Riyard bin Kiflee, Nornajihah Nadia binti Hasbullah, Nur Shahida Binti Ab Fatah, Mohd Noor Azli bin Ali Khan

To Link this Article: http://dx.doi.org/10.6007/IJARBSS/v11-i11/11412

DOI:10.6007/IJARBSS/v11-i11/11412

Received: 16 September 2021, Revised: 20 October 2021, Accepted: 28 October 2021

Published Online: 15 November 2021

In-Text Citation: (Kiflee et al., 2021)

To Cite this Article: Kiflee, A. K. R. bin, Hasbullah, N. N. binti, Fatah, N. S. B. A., \& Khan, M. N. A. bin A. (2021). Corporate Social Responsibility Research- Bibliometric Insight. International Journal of Academic Research in Business and Social Sciences, 11(11), 2058-2078.

Copyright: (c) 2021 The Author(s)

Published by Human Resource Management Academic Research Society (www.hrmars.com)

This article is published under the Creative Commons Attribution (CC BY 4.0) license. Anyone may reproduce, distribute, translate and create derivative works of this article (for both commercial and non0-commercial purposes), subject to full attribution to the original publication and authors. The full terms of this license may be seen

at: http://creativecommons.org/licences/by/4.0/legalcode

Vol. 11, No. 11, 2021, Pg. $2058-2078$

http://hrmars.com/index.php/pages/detail/IJARBSS

JOURNAL HOMEPAGE

Full Terms \& Conditions of access and use can be found at http://hrmars.com/index.php/pages/detail/publication-ethics 


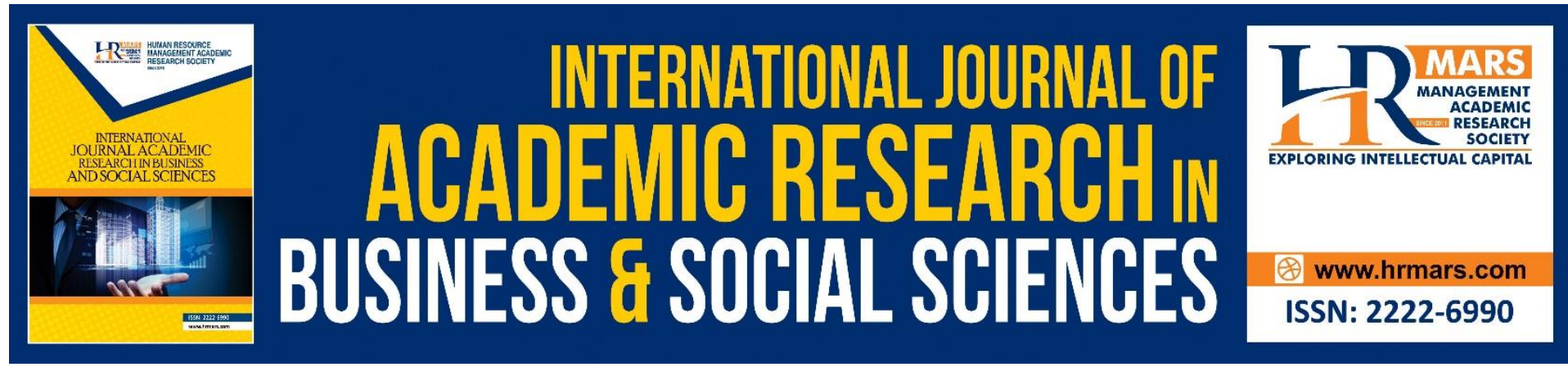

\title{
Corporate Social Responsibility Research- Bibliometric Insight
}

\author{
Ag Kaifah Riyard bin Kiflee ${ }^{1}$, Nornajihah Nadia binti Hasbullah², \\ Nur Shahida Binti Ab Fatah ${ }^{3}$, Mohd Noor Azli bin Ali Khan ${ }^{4}$ \\ ${ }^{1,3}$ Faculty of Business, Economics and Accountancy, Universiti Malaysia Sabah, ${ }^{2}$ Faculty of \\ Business Management, Universiti Teknologi Mara (UiTM), Johor Branch, Pasir Gudang \\ Campus, ${ }^{4}$ Azman Hashim International Business School, Universiti Teknologi Malaysia, Johor \\ Email: Agkaifah@ums.edu.my
}

\begin{abstract}
Given on the importance of social accounting for sustainable development, this study objectives are to investigate the global trends of CSRD from the perspective of publications outputs, co-authorship, countries, and authors co-occurrences keywords. CSR activities and disclosure practices are arguably important as mean to improve social communication between company to stakeholder. It is being emphasised that, understanding the subject of interest and widening the networking is important to improve the research from many perspectives. From 1959 to 2019, a total of 181 articles were extracted from Scopus database for analysis purpose. Result analysis suggested that, publications on CSRD have experienced positive upwards from 2013 until 2019, contributing to total cumulative of CSRD articles. More than half of CSRD articles were published by UK researchers, China and Malaysia, leading other countries. Due to the nature of research, most of the CSRD articles were contributed by academic institutions. In an attempt to further CSRD research, Islamic banks, performance and managerial ownership were seen as potential topics to be expanded by future research.
\end{abstract}

Keywords: CSR, Bibliometric Analysis, Scopus, VOSviewer

\section{Introduction}

A disclosure is an extensive information sharing which includes company disclosure motivation, objectives and financial strategic plan (Evans and Sridhar, 2002). Cormier and Magnan (2003); Hutton et al (2003) and Sinclair Desgagne and Gozlan (2003) stated that, an extensive disclosure should also cover sales/earning forecast, rotations in top management, social and environmental issues as well as media coverage of the company. Several major incidents and complications of social report itself has triggered the corporate social responsibility (CSR) awareness among consumers, investors, employees, creditors, legislators and regulator (Brown and Deegan, 1998; Brammer and Pavelin, 2004). Majority of large company has volunteered to report their activities which primarily concern on society wellbeing in which this positively impacts their performance (Gray et al., 1995; Deegan and Gordon, 1996). In response to this practice, academic researchers specifically are interested 
to examine the content of company voluntary disclosure primarily from the statement of corporate governance and social, environmental and safety report (Patten, 2002).

However, it is to note that not all companies opted for voluntary social disclosure and if the company do they may apply a variety of disclosure methods due to high-cost utilisation. This is because cost of measuring and verifying social impact including administrative burden of publishing the information is high. Therefore, it is to expect that the extent of company disclosure is depending on the cost and benefits that they potentially acquire (Cormier, Gordon and Magnan, 2004). Current social disclosure literature suggests that, disclosure cost and benefit may vary depending on the pressure from various parties such as legislators, regulators, environmental concern groups, consumers and prospects investors (SinclairDesgagne' and Gozlan, 2003; Willis, 2003). In addition, company size, media exposure (Patten, 2002), environmental performance (Patten, 2002), governance structures and resources availability (Cullen and Christopher, 2002; Cormier and Magnan, 2003) also influence the degree of disclosure from the company

Besides company business nature, it is also argued that company social performance is also influencing the willingness of the company to disclose social information (Brammer and Pavelin, 2004). Earlier studies suggested that, company social disclosure is heavily depending on their social performance as higher social performance will allow the company to report good news and secluding them from reporting bad news (Hooghiemstra, 2000). However, the result concerning on this matter is rather mix (Ullmann, 1985). From stakeholder viewpoint, it is expected positive association between social performance and social disclosure. This is due to the fact that company is responsible to disclose useful social information for the investor decision purpose.

Mega companies who have been praised for their contribution to the development of economic and technological progress have been critised for inducing social issues to the market. Pollution, resources exhaustion, monopoly and poor workers welfare are some of the problems caused by the mega companies which are getting much attention (Reverte, 2009). Therefore, companies have been urged to focus on a wider scope than satisfying the shareholders wellbeing (Reverte, 2009). Public current issues such as environmental and social problems are some of the issues that should be tackled by the companies.

Despite the significant interest in the study of corporate social disclosure, it was found that, there is little evidence who pointed in measuring and analysing the scientific publications of corporate social disclosure. This has motivated this study to:

- Further investigate the publications trend of CSRD (corporate social responsible disclosure)

- Determine the top leading journals, authors, countries also academic institutions in CSRD

- Identify common terminology research in CSRD

- Identify the current limitations and also suggestion for potential research topic related to CSRD

\section{Methods}

\section{Inclusion Characteristics}

Bibliometric analysis is an analysis technique who developed in order to understand the publications trends over a specific topic. This criterion has to differentiate bibliometric analysis from a review paper which bibliometric analysis primarily focusses on discussing current progress, limitations and future directions of some topics (Khudzari et al., 2018). 


\section{Exclusion Characteristics}

This study has set to exclude (i) identical publications, conferences minutes and papers with insufficient research and analysis on CSRD (ii) any review, advance, critical, revisit and recent paper on CSRD and (iii) also incomplete papers.

\section{Data Sources and Search Strategy}

Data extraction was carried out between 4 to 5 August, 2020 by using Scopus database. To extract the CSRD articles, the researchers applied search keywords of "Corporate* Social* responsibility* Disclosure*" in both the title and abstract of the paper. Based on the analysis, it was suggested the first paper related to CSRD was published back in 1987 and the latest is 2019. To filter the articles, the researcher applied query string ( TITLEABS ( "corporate* social* responsibility* disclosure*" ) ) which resulted in 272 CSRD. Additionally, researchers also exclude any review, recent, progress and critical articles by adding additional keywords in search query which resulting in 17 articles which identified as inappropriate for this study. To ensure the exclude articles are correct, the researchers reread the title and abstract of the article's for multiple times. The results then suggested that, all the 17 articles are containing the exclusion terms which qualify them to be excluded from the total CSRD articles. To exclude articles automatically or by search string, an EIF, which is Scopus unique identification number is being added into the search string ( AND NOT ( EID ( 2-s2.0-85067874084... ) to work as filter tool.

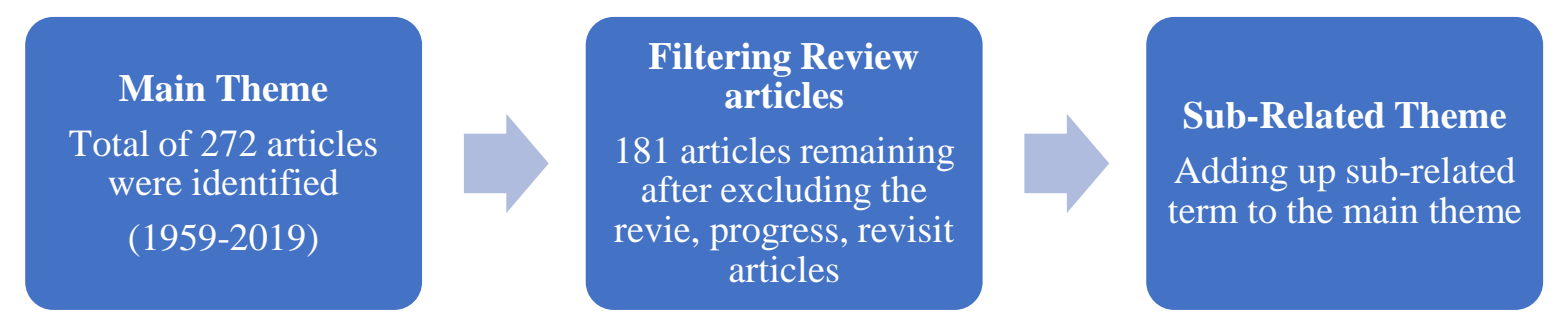

Figure 1

Study also determined that the best method to obtain the authors publications output is to use the author ID instead of their last name (Scopus field code: AU-ID). As mentioned, an author profile consists of a variety of information such as Scopus ID, affiliation and $\mathrm{H}$-index which arguably useful to identify CSRD top authors. While, information for a single country (SCP) publication was extracted by excluding other countries and only delimiting to chosen country.

The articles then were analysed based on year, sources, authors, affiliation, territory, and their subject area. Whereas, to determine articles ranking, the researcher will enquire the total publications, total citations, CiteScore and $\mathrm{H}$-index of the articles.

In addition, this study also intends to examine the attributes which affect CSRD. The attributes that employed in this study are (i) size of the company, (ii) performance, (iii) ownership structure, (iv) international listing and (v) leverage. These attributes were studied repeatedly and found to affect the company CSRD. The attributes were chosen based on their frequent appearance in other CSRD studies. 
The process of finding and filtering all the CSRD articles is summarised in Figure 1. Whereas Table 1 displayed the details on search string employed to extract CSRD articles on Scopus.

\section{Bibliometric Maps}

All the citations, bibliographical, and author keywords information for 181 articles were analysed by using VOSviewer (version 1.6.7, Centre for Science and Technology Studies, Leiden University, The Netherlands), to generate the bibliometric maps. To generate bibliometric maps, the VOSviewer required an item such as countries and author keywords. To mentioned, between any pairs of the items, there are connecting link where each links strength is represented through the density of the colour. The darker the link colour between the items, the stronger the link is (Khudzari et al., 2018).

Whereas, in the sense of co-authorship analysis, the link connecting between countries represents the number of publications with other co-authored in different countries and the total link strength represents the total publications of co-authorship with other countries. Correspondingly, in the sense of co-occurrence analysis, the link strength between the identified keywords represents the total publications where the keywords are employed together. VOSviewer full features and function can be found in the user manual (Van Eck and Waltman, 2018).

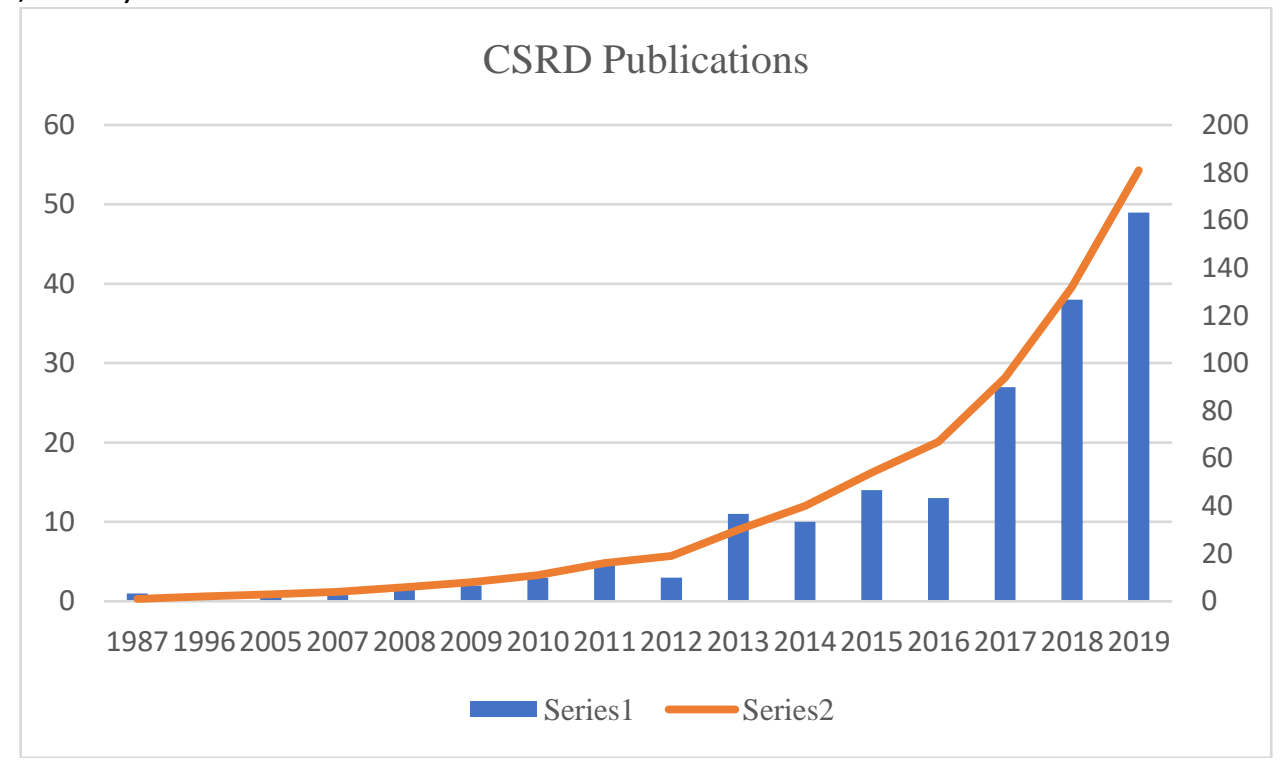

\section{Analysis of Co-Authorship}

Figure 2

For the co-authorship analysis, the researchers identified at least 434 authors from 50 countries affiliated to each other. The affiliated countries then divided into 5 continents which are Asia, Europe, America, Africa and Oceania.

\section{Analysis of Co-Occurrences}

The result of co-occurrences author keywords analysis comprises 434 keywords from 181 articles. The remaining 17 articles were excluded as the articles were not fulfilling within the context of the study. Prior to further analysis of author keywords in the VOSviewer, synonymous single word test was conducted. For example, corporate social responsibility, corporate social responsibilities disclosures, corporate social responsibility (csr) disclosures, 
and corporate social disclosure were also identified as corporate social responsibility disclosure.

During the analysis, minimum occurrences of keywords were set to 1 . To observe the yearly publication average, number of occurrences and strength link of keywords were analysed by choosing overlay visualisation in VOSviewer. The colour of keywords represents the article's publication. The lighter the colour density of the keywords, represent the current publication articles.

\section{CSRD Applications}

To determine the CSRD trend, the search output between CSRD co-occurences and total publications was compared. This study chooses corporate social responsibility as a subject of study, thus all related keywords such as corporate social disclosure, social disclosure, environmental disclosure and corporate social reporting in VOSviewer were counted. Moreover, for detail analysis, researcher also analysed the top five countries who actively publish in CSRD fields.

\section{Results and Discussions}

\section{Publication Outcome and CSRD Research Trends}

In the last 32 years, a total of 181 articles related to CSRD had been published (referred to Figure 2). The first CSRD publications were found back in 1987 and until 1996, there are single publications of CSRD paper. However, in 2010, the amount of CSRD paper published is increasing doubled and the amount continues to increase in the momentous paper. In the last 3 years, the annual publications of CSRD paper are increasing and this contribute to the higher cumulative publications. Therefore, it is expected that the annual publications of CSRD articles will continue to increase based on the current trend. One of the issues that encounter by the researcher during the extracting process is, some of the articles in the Scopus is not under free access. The analysis documented that those articles who published with free access are likely to receive higher citations (Khudzari et al., 2018).

On the whole, CSRD research is rather broad and this has motivated numerous research groups to extend the current CSRD literature. By referring to subject area analysis, it was suggested that most of CSRD paper are published under business, management and accounting (143). Another subject area which related to CSRD is economics, econometrics and finance (74), social science (59), environmental science (23) and the arts and humanities (18). Therefore, based on the subject area analysis, CSRD can be classified as a multidiscipline area as some of the papers also published in Art and Humanities field.

\section{Publication Language}

Publication's analysis showed that the articles were written in three different languages. Most of the CSRD articles were written in English with 98 percent, followed by Chinese and Thai languages with 1 percent each. (Khudzari et al., 2018) stated that, an article that were published in other than the English language may also accepted as Scopus required both of the articles title and abstract to be written in English.

\section{Top Journals Selection}

CSRD journal analysis disclosed that, 15 most successful journal was published from ten different publishers. Emerald in the first rank with 3 journals and followed by Springer and Allied Academics with two journals. The remaining publisher is Serials Publications, Wiley- 
Blackwell, Multidisciplinary Digital Institute (MDPI) and Virtus Interpress with single journal respectively.

The analysis also found that Social Responsibility Journal is the top productive journal with 14 articles, encompasses $17.5 \%$ from the total publications. This is followed then by Journal of Business Ethics with 12 articles (15\%). Corporate Social Responsibility and Environmental Management (6 articles, 7.5\%), Managerial Auditing Journal (5 articles, 6.25\%) and Sustainability Accounting Management and Policy Journal (4 articles, 5\%) are the remaining top journal in CSRD. The analysis also revealed that, despite being ranks as the second top productive journals, Journal of Ethics received the highest citations with 998 times and CiteScore of 7. Similar situation also can be observed from Managerial Auditing Journal as the number of citations received is higher than $4^{\text {th }}$ ranked list (Corporate Social Responsibility and Environmental Management). Moreover, one of the articles that published in 2013 in Journal of Business Ethics has received the highest citations with 303 times.

CiteScore analysis suggested that there are six journals with CiteScore of 3 and above. Among the journals are Journal of Business Ethics (7), Sustainability Switzerland (3.2), Corporate Social Responsibility and Environmental Management (5.9) and Sustainability Accounting Management and Policy Journal (3.8). The analysis indicates that the highest score was belonging to the Journal of Business Ethics (7) and Entrepreneurship and Sustainability Issues (7) while International of Economic Research and International Journal of Economics have the least CiteScore with zero (0).

Specifically, the score of journals CiteScore may affect authors selection decision as they only publish in high quality journal that fulfils their certain criteria. CiteScore is similar to Clarivate Analytics Impact Factor in WOS (web of science) where the functions are to measure the journal impact. However, it is to note that, CiteScore is not only the selection indicator when choosing the right journal. Besides CiteScore, other important criteria that should be considered by the authors are whether the chosen journal is capable to relay the articles to the right audience and contributes to the body of knowledge. 
INTERNATIONAL JOURNAL OF ACADEMIC RESEARCH IN BUSINESS AND SOCIAL SCIENCES Vol. 11, No. 11, 2021, E-ISSN: 2222-6990 @ 2021 HRMARS

Table 1

\begin{tabular}{|c|c|c|c|c|c|c|c|c|}
\hline Rank & Journal & $\begin{array}{l}\text { Number of } \\
\text { publications }\end{array}$ & $\%$ & $\begin{array}{l}\text { Number } \\
\text { of } \\
\text { citations }\end{array}$ & $\begin{array}{l}\text { Cite score } \\
2019\end{array}$ & The Most Cited Article & $\begin{array}{l}\text { Times } \\
\text { cited }\end{array}$ & Publisher \\
\hline 1. & $\begin{array}{l}\text { Social } \\
\text { Responsibility } \\
\text { Journal }\end{array}$ & 14 & 17.5 & 414 & 2.5 & $\begin{array}{l}\text { The relationship between } \\
\text { corporate social } \\
\text { responsibility disclosure } \\
\text { and corporate governance } \\
\text { characteristics in Malaysian } \\
\text { public listed companies }\end{array}$ & 216 & Emerald \\
\hline 2. & $\begin{array}{l}\text { Journal of } \\
\text { Business Ethics }\end{array}$ & 12 & 15 & 998 & 7.0 & $\begin{array}{l}\text { Corporate Governance and } \\
\text { Corporater Social } \\
\text { Responsibility Disclosures: } \\
\text { Evidence from an Emerging } \\
\text { Economy }\end{array}$ & 303 & Springer Nature \\
\hline 3. & $\begin{array}{l}\text { Sustainability } \\
\text { Switzerland }\end{array}$ & 8 & 10 & 76 & 3.2 & $\begin{array}{l}\text { Determinants of corporate } \\
\text { social responsibility } \\
\text { disclosure: An empirical } \\
\text { study of Polish listed } \\
\text { companies }\end{array}$ & 39 & $\begin{array}{l}\text { Multidisciplinary } \\
\text { Digital Publishing } \\
\text { Institute (MDPI) }\end{array}$ \\
\hline 4. & $\begin{array}{l}\text { Corporate } \\
\text { Ownership And } \\
\text { Control }\end{array}$ & 6 & 7.5 & 34 & 0.2 & $\begin{array}{l}\text { Factors affecting corporate } \\
\text { social responsibility } \\
\text { disclosure in Egypt }\end{array}$ & 21 & Virtus Interpress \\
\hline 5. & $\begin{array}{l}\text { Corporate } \\
\text { Social } \\
\text { Responsibility } \\
\text { And } \\
\text { Environmental } \\
\text { Management }\end{array}$ & 6 & 7.5 & 221 & 5.9 & $\begin{array}{l}\text { The integration of } \\
\text { corporate governance in } \\
\text { corporate social } \\
\text { responsibility disclosures }\end{array}$ & 107 & Wiley-Blackwell \\
\hline 6. & $\begin{array}{l}\text { Managerial } \\
\text { Auditing Journal }\end{array}$ & 5 & 6.25 & 244 & 2.7 & $\begin{array}{l}\text { Corporate social } \\
\text { responsibility disclosures } \\
\text { over time: Evidence from } \\
\text { Malaysia }\end{array}$ & 82 & Emerald \\
\hline
\end{tabular}


INTERNATIONAL JOURNAL OF ACADEMIC RESEARCH IN BUSINESS AND SOCIAL SCIENCES Vol. 11, No. 11, 2021, E-ISSN: 2222-6990 @ 2021 HRMARS

\begin{tabular}{|c|c|c|c|c|c|c|c|c|}
\hline Rank & Journal & $\begin{array}{l}\text { Number of } \\
\text { publications }\end{array}$ & $\%$ & $\begin{array}{l}\text { Number } \\
\text { of } \\
\text { citations }\end{array}$ & $\begin{array}{l}\text { Cite score } \\
2019\end{array}$ & The Most Cited Article & $\begin{array}{l}\text { Times } \\
\text { cited }\end{array}$ & Publisher \\
\hline 7. & $\begin{array}{l}\text { Academy Of } \\
\text { Accounting And } \\
\text { Financial } \\
\text { Studies Journal }\end{array}$ & 4 & 5 & 9 & 0.9 & $\begin{array}{l}\text { The effect of good } \\
\text { corporate governance and } \\
\text { earnings management to } \\
\text { corporate social } \\
\text { responsibility disclosure }\end{array}$ & 5 & Allied Academies \\
\hline 8. & $\begin{array}{l}\text { International } \\
\text { Journal Of } \\
\text { Economic } \\
\text { Research }\end{array}$ & 4 & 5 & 1 & 0.0 & $\begin{array}{l}\text { The shariah enterprise } \\
\text { theory: Implementation of } \\
\text { corporater social } \\
\text { responsibility disclosure for } \\
\text { Islamic Banking in Indonesia } \\
\text { and Malaysia }\end{array}$ & 1 & Serials Publications \\
\hline 9. & $\begin{array}{l}\text { Sustainability } \\
\text { Accounting } \\
\text { Management } \\
\text { And Policy } \\
\text { Journal }\end{array}$ & 4 & 5 & 85 & 3.8 & $\begin{array}{l}\text { Firm ownership and board } \\
\text { characteristics: Do they } \\
\text { matter for corporate social } \\
\text { responsibility disclosure of } \\
\text { Indian Companies? }\end{array}$ & 41 & Emerald \\
\hline 10. & $\begin{array}{l}\text { Accounting And } \\
\text { Finance }\end{array}$ & 3 & 3.75 & 21 & 2.5 & $\begin{array}{l}\text { Strange bedfellows? } \\
\text { Voluntary corporate social } \\
\text { responsibility disclosure } \\
\text { and politics }\end{array}$ & 16 & $\begin{array}{l}\text { Accounting And } \\
\text { Finance }\end{array}$ \\
\hline 11. & $\begin{array}{l}\text { Entrepreneursh } \\
\text { ip And } \\
\text { Sustainability } \\
\text { Issues }\end{array}$ & 3 & 3.75 & 32 & 7.0 & $\begin{array}{l}\text { Corporate social } \\
\text { responsibility disclosure: } \\
\text { Evidence from the } \\
\text { european retail sector }\end{array}$ & 12 & $\begin{array}{c}\text { Entrepreneurship } \\
\text { and Sustainability } \\
\text { Center }\end{array}$ \\
\hline 12. & $\begin{array}{l}\text { International } \\
\text { Journal Of } \\
\text { Economics And } \\
\text { Financial Issues }\end{array}$ & 3 & 3.75 & 25 & - & $\begin{array}{l}\text { Ownership structure and } \\
\text { corporate social } \\
\text { responsibility disclosure in } \\
\text { Bangladesh }\end{array}$ & 20 & EconJournals \\
\hline 13. & $\begin{array}{l}\text { International } \\
\text { Journal Of }\end{array}$ & 3 & 3.75 & 1 & 0.5 & $\begin{array}{l}\text { The influence of corporate } \\
\text { social responsibility }\end{array}$ & 1 & $\begin{array}{c}\text { Primrose Hall } \\
\text { Publishing Group }\end{array}$ \\
\hline
\end{tabular}


INTERNATIONAL JOURNAL OF ACADEMIC RESEARCH IN BUSINESS AND SOCIAL SCIENCES Vol. 11, No. 11, 2021, E-ISSN: 2222-6990 @ 2021 HRMARS

\begin{tabular}{|c|c|c|c|c|c|c|c|c|}
\hline Rank & Journal & $\begin{array}{l}\text { Number of } \\
\text { publications }\end{array}$ & $\%$ & $\begin{array}{l}\text { Number } \\
\text { of } \\
\text { citations }\end{array}$ & $\begin{array}{l}\text { Cite score } \\
2019\end{array}$ & The Most Cited Article & $\begin{array}{l}\text { Times } \\
\text { cited }\end{array}$ & Publisher \\
\hline & $\begin{array}{l}\text { Innovation } \\
\text { Creativity And } \\
\text { Change }\end{array}$ & & & & & $\begin{array}{l}\text { disclosure, managerial } \\
\text { ownership and firm size on } \\
\text { firm value in Indonesia } \\
\text { stock exchange }\end{array}$ & & \\
\hline 14. & $\begin{array}{l}\text { Review } \\
\text { Managerial } \\
\text { Science }\end{array}$ & 3 & 3.75 & 65 & 4.4 & $\begin{array}{lr}\text { Corporate } & \text { social } \\
\text { responsibility } & \text { disclosure } \\
\text { and market valuation: } & \text { vanish } \\
\text { evidence from Spanish } & \\
\text { listed firms } & \end{array}$ & 31 & Springer Nature \\
\hline 15. & $\begin{array}{l}\text { Academy Of } \\
\text { Strategic } \\
\text { Management } \\
\text { Journal }\end{array}$ & 2 & $2.5 \mathrm{w}$ & 1 & 1.7 & $\begin{array}{l}\text { Corporate social } \\
\text { responsibility disclosure in } \\
\text { malaysian business }\end{array}$ & 1 & $\begin{array}{l}\text { Allied Business } \\
\text { Academies }\end{array}$ \\
\hline
\end{tabular}




\section{Top Countries, Institutions and Affiliation Authors}

Table 2 demonstrated 15 most productive countries who actively share CSRD articles in the academic world. Surprisingly, the analysis showed that more than half of the CSRD publication were published by Indonesia and United Kingdom. This has placed them as the top countries who actively share in the CSR field. Statistics analysis suggested that Indonesia has published 31 articles alone in CSRD followed by UK with 27 articles at the second place. Although UK was placed as second most productive country, the total publication from their academic institutions (University Plymouth) is significantly higher than Indonesia academic institutions. This is due to the factors that most of the Indonesian publications are associated with other country researchers. In addition, despite being ranked as 4th most prolific country, Australia through University Deaking is the most productive institutions with 9 published articles.

From 15 top countries being analysed, only three countries (Indonesia, Spain and India) to have more than half of their publications are single-country publications (SCP) with 90\%, 83.33\% and 66.37\%. Notwithstanding, Hong Kong, Canada and Egypt are among the three countries with non-SCP whereby all of their publications are joint venture with other countries researchers. Among the benefit of affiliation, especially international affiliations are transferring knowledge and exchange expertise and also one of the ways to improve authors ranked. For example, half of United Kingdom total publications are affiliated with other countries and the result has showed that, most of their paper are published in highly ranked journal, indicating their high-quality articles.

In addition, Table 2 also showed top academic institutions who actively writing in CSRD field. Among the top universities are Deakin University with 9 articles, Xi'an Jiaoton University and University of Portsmouth with 5 articles. This demonstrated that CSRD work is getting much attention from global researchers.

Figure 3 is VOSviewer map that represents the distribution of CSRD countries in each region. The map suggested that, the closer the location between the two countries, the stronger their relations which can observe from the thickness of the line. Analysis of top countries has found that, Asia is the leading region with 24 countries, followed by Europe (12), Africa (7), USA (3) and Oceania (2). Co-authorship analysis also suggested UK is the top affiliated country with 16 connecting link to others and followed by Australia with 9 links, USA (8 links), Malaysia (6 links) and Hong Kong ( 6 links). The map also suggested that, more than half of the total countries were associated with other countries. Based on co-authorship analysis, 14 countries are found attempted to publish by their own, not to collaborate with others.

There are various factors that lead to successful international collaboration such as comprehensive and skilled research partners, and number of international postgraduate's students in one country. The study also agreed that, stable research policy by academic institutions may secure and attract more international collaboration 
INTERNATIONAL JOURNAL OF ACADEMIC RESEARCH IN BUSINESS AND SOCIAL SCIENCES Vol. 11, No. 11, 2021, E-ISSN: 2222-6990 @ 2021 HRMARS

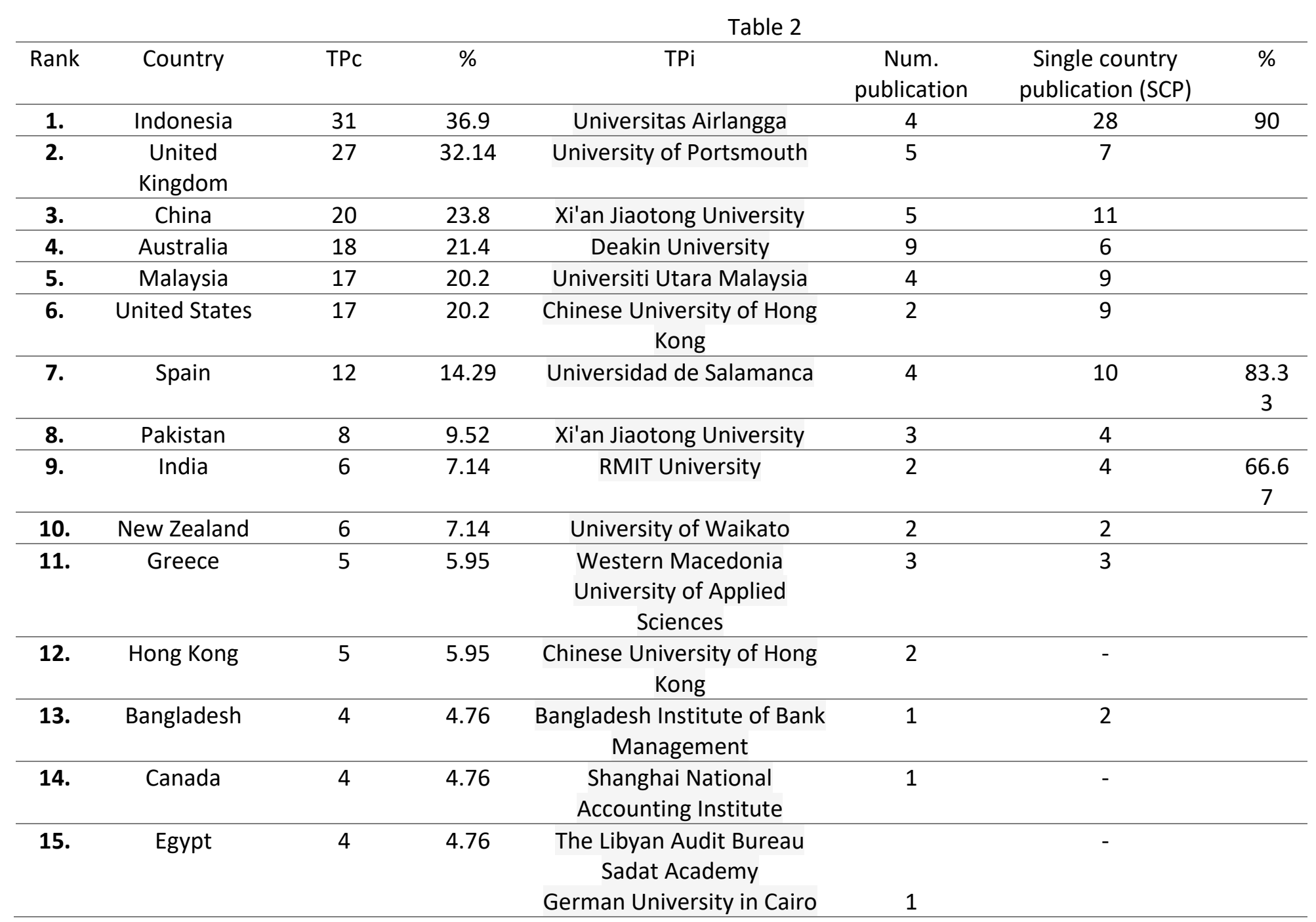




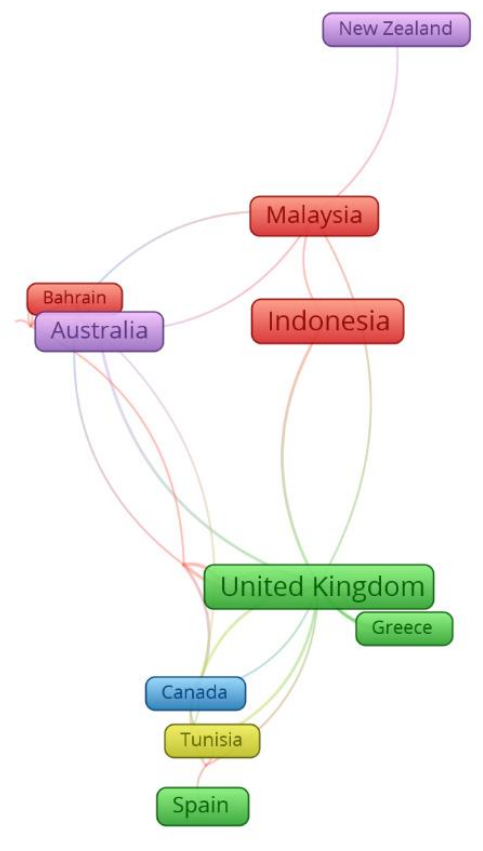

\section{Top CSRD Authors}

Figure 3

Table 3 showed the list of the most prolific authors in CSRD which affiliated with eight countries. Among the affiliated countries are Australia ( 2 authors), UK (5 authors), Portugal ( 2 authors), Spain ( 2 authors), Greece (1 author), Tunisia ( 1 author), China ( 1 author) and USA (1 author). By referring to publication ranks, it is to observe that most of the CSRD authors are corresponding authors ( 8 authors), 2 as co-authors and 5 authors were ranked as last authors. Although there are no specific rules in determining the authors ranked, usually, the last authorship probably belong to supervisor or non-academic individual. The association of CSRD authors suggested, CSRD not only related to business and accounting, but also with human and art as well as economics and finance.

Based on CSRD most prolific authors analysis, it is found that Muttakin, Mohammad Badrul is the top ranks authors with 6 publications, $\mathrm{H}$-Index of 6 and 432 citations. Next prolific author was belonging to Khan, Arifur, with 392 citations and Dixon, Rob with 245 citations respectively. Although Dixon, Rob being ranked as the second last prolific authors, one of the papers has received higher citations which ranked Dixon, Rob to the top 3 CSRD publications. Both of the authors were affiliated with Deakin University and Durham University Business School respectively. Next most prolific authors were belonging to García-Sánchez, Isabel María and Giannarakis, Grigoris who are ranked 4th and 5th respectively. both of the authors of current affiliation was from Europe as both authors were originated from Spain and Greece.

It also stated, the possibility for top articles who exist in Table 1 to be present in the list of prolific authors (Table 3 ) when the authors able to published high quality articles who received significant citations number such as Khan, Arifur and Hussainey, Khlaed. 
INTERNATIONAL JOURNAL OF ACADEMIC RESEARCH IN BUSINESS AND SOCIAL SCIENCES Vol. 11, No. 11, 2021, E-ISSN: 2222-6990 @ 2021 HRMARS

\begin{tabular}{|c|c|c|c|c|c|c|c|c|c|}
\hline $\begin{array}{c}\text { Ran } \\
k\end{array}$ & Authors & $\begin{array}{c}\text { Rank } \\
\text { Author } \\
\text { s }\end{array}$ & $\begin{array}{l}\text { Scopus } \\
\text { Author Id }\end{array}$ & $\begin{array}{c}\text { Years Of } \\
1^{\text {st }} \\
\text { Publicatio } \\
n\end{array}$ & $\begin{array}{c}\text { Total } \\
\text { Publication } \\
\mathrm{s}\end{array}$ & $\begin{array}{c}\mathrm{H}- \\
\text { Inde } \\
\mathrm{x}\end{array}$ & $\begin{array}{c}\text { Total } \\
\text { Citation } \\
\text { s }\end{array}$ & $\begin{array}{c}\text { Current } \\
\text { Affiliation }\end{array}$ & Country \\
\hline 1. & Khan, Arifur & 1 & $\begin{array}{c}5547340260 \\
0\end{array}$ & 2013 & 6 & 5 & 392 & $\begin{array}{l}\text { Deakin } \\
\text { University }\end{array}$ & $\begin{array}{l}\text { Geelong, } \\
\text { Australia }\end{array}$ \\
\hline 2. & $\begin{array}{l}\text { Muttakin, Mohamma } \\
\text { d Badrul }\end{array}$ & 2 & $\begin{array}{c}5521813020 \\
0\end{array}$ & 2013 & 6 & 6 & 432 & $\begin{array}{l}\text { Deakin } \\
\text { University }\end{array}$ & $\begin{array}{l}\text { Geelong, } \\
\text { Australia }\end{array}$ \\
\hline 3. & Hussainey, Khaled & 1 & $\begin{array}{c}1644423090 \\
0\end{array}$ & 2011 & 4 & 3 & 43 & $\begin{array}{c}\text { Portsmouth } \\
\text { Business } \\
\text { School } \\
\end{array}$ & $\begin{array}{l}\text { Portsmouth } \\
\text {, United } \\
\text { Kingdom }\end{array}$ \\
\hline 4. & Craig, R. J. & 3 & 7402946287 & 2016 & 3 & 3 & 45 & $\begin{array}{c}\text { Durham } \\
\text { University } \\
\text { Business } \\
\text { School }\end{array}$ & $\begin{array}{l}\text { Durham, } \\
\text { United } \\
\text { Kingdom }\end{array}$ \\
\hline 5. & Dias, António Gomes & 1 & $\begin{array}{c}5719141536 \\
4\end{array}$ & 2016 & 3 & 3 & 45 & $\begin{array}{l}\text { University } \\
\text { of Trás-os- } \\
\text { Montes and } \\
\text { Alto Douro }\end{array}$ & $\begin{array}{l}\text { Vila Real, } \\
\text { Portugal }\end{array}$ \\
\hline 6. & $\begin{array}{c}\text { García- } \\
\text { Sánchez, Isabel María }\end{array}$ & 3 & $\begin{array}{c}5719336376 \\
7\end{array}$ & 2015 & 3 & 3 & 62 & $\begin{array}{l}\text { Universidad } \\
\text { de } \\
\text { Salamanca }\end{array}$ & $\begin{array}{l}\text { Salamanca, } \\
\text { Spain }\end{array}$ \\
\hline 7. & Giannarakis, Grigoris & 1 & $\begin{array}{c}2653409980 \\
0\end{array}$ & 2013 & 3 & 2 & 56 & $\begin{array}{l}\text { University } \\
\text { of Western } \\
\text { Macedonia }\end{array}$ & $\begin{array}{l}\text { Kozani, } \\
\text { Greece }\end{array}$ \\
\hline 8. & Edward Lee, Edward & 1 & $\begin{array}{c}2300546380 \\
0\end{array}$ & 2017 & 3 & 2 & 45 & $\begin{array}{c}\text { Alliance } \\
\text { Manchester }\end{array}$ & $\begin{array}{c}\text { Manchester } \\
\text {, United } \\
\text { Kingdom }\end{array}$ \\
\hline
\end{tabular}


INTERNATIONAL JOURNAL OF ACADEMIC RESEARCH IN BUSINESS AND SOCIAL SCIENCES Vol. 11, No. 11, 2021, E-ISSN: 2222-6990 @ 2021 HRMARS

\begin{tabular}{|c|c|c|c|c|c|c|c|c|c|}
\hline $\begin{array}{c}\text { Ran } \\
k\end{array}$ & Authors & $\begin{array}{c}\text { Rank } \\
\text { Author } \\
\mathrm{s}\end{array}$ & $\begin{array}{l}\text { Scopus } \\
\text { Author Id }\end{array}$ & $\begin{array}{c}\text { Years Of } \\
1^{\text {st }} \\
\text { Publicatio } \\
n\end{array}$ & $\begin{array}{c}\text { Total } \\
\text { Publication } \\
\mathrm{s}\end{array}$ & $\begin{array}{c}\mathrm{H}- \\
\text { Inde } \\
x\end{array}$ & $\begin{array}{c}\text { Total } \\
\text { Citation } \\
\text { s }\end{array}$ & $\begin{array}{c}\text { Current } \\
\text { Affiliation }\end{array}$ & Country \\
\hline & & & & & & & & $\begin{array}{l}\text { Business } \\
\text { School, }\end{array}$ & \\
\hline 9. & Lima Rodrigues, Lúcia & 2 & $\begin{array}{c}5720974746 \\
1\end{array}$ & 2016 & 3 & 3 & 45 & $\begin{array}{l}\text { Universidad } \\
\text { e do Minho }\end{array}$ & $\begin{array}{c}\text { Braga, } \\
\text { Portugal }\end{array}$ \\
\hline 10. & Zeng, Cheng (Colin) & 3 & $\begin{array}{c}5720192156 \\
9\end{array}$ & 2017 & 3 & 2 & 45 & $\begin{array}{c}\text { Alliance } \\
\text { Manchester } \\
\text { Business } \\
\text { School }\end{array}$ & $\begin{array}{l}\text { Manchester } \\
\text {, United } \\
\text { Kingdom }\end{array}$ \\
\hline 11. & Boussaada, Rim & 3 & $\begin{array}{c}5606983680 \\
0 \\
\end{array}$ & 2019 & 2 & 1 & 4 & $\begin{array}{l}\text { Université } \\
\text { de Tunis }\end{array}$ & $\begin{array}{l}\text { Tunis, } \\
\text { Tunisia }\end{array}$ \\
\hline 12. & Cai, Weixing & 1 & $\begin{array}{c}5600394960 \\
0\end{array}$ & 2017 & 2 & 2 & 6 & $\begin{array}{l}\text { Guangdong } \\
\text { University } \\
\text { of Finance }\end{array}$ & $\begin{array}{l}\text { Guangzhou, } \\
\text { China }\end{array}$ \\
\hline 13. & $\begin{array}{c}\text { Cuadrado- } \\
\text { Ballesteros, Beatriz }\end{array}$ & 1 & $\begin{array}{c}5156587740 \\
0\end{array}$ & 2015 & 2 & 2 & 51 & $\begin{array}{l}\text { Universidad } \\
\text { de } \\
\text { Salamanca }\end{array}$ & $\begin{array}{l}\text { Salamanca, } \\
\text { Spain }\end{array}$ \\
\hline 14. & Dixon, Rob & 3 & $\begin{array}{c}5698313350 \\
0\end{array}$ & 2014 & 2 & 2 & 245 & $\begin{array}{c}\text { Durham } \\
\text { University } \\
\text { Business } \\
\text { School }\end{array}$ & $\begin{array}{c}\text { Durham, } \\
\text { United } \\
\text { Kingdom }\end{array}$ \\
\hline 15. & Griffin, Paul A. & 1 & $\begin{array}{c}3601513250 \\
0\end{array}$ & 2013 & 2 & 2 & 22 & $\begin{array}{c}\text { University } \\
\text { of } \\
\text { California, } \\
\text { Davis, }\end{array}$ & $\begin{array}{l}\text { Davis, } \\
\text { United } \\
\text { States }\end{array}$ \\
\hline
\end{tabular}




\section{Keywords Analysis}

Based on the authors keywords analysis, the analysis showed that, 403 keywords were used once, 95 keywords were used twice and 44 keywords were used more than twice. The study also analyses the synonymous keywords and identical phrases and agreed to set the VOSviewer minimum occurrences into 1.

\section{Top Employed Keywords}

The result implied that the most popular term that employed by CSRD researcher is 'corporate social responsibility' with occurrences of 92 and link to another 222 keywords. among other CSRD keywords that frequently employed by the researcher is corporate governance (41 occurences, 102 links), voluntary disclosure (8 occurrences, 27 links) and information disclosure (4 occurrences, 9 links). based VOSviewer map, it is learned that 'corporate social responsibility' also associated with other keywords such as 'legitimacy theory', 'cost of capital', 'islamic financial institutions' and 'earning management'.

This study also recognises several synonyms that frequently employed by other CSRD researcher which referring to CSRD such as 'CSR disclosure' (18 occurrences), 'CSR reporting' (3), 'sustainability reporting' (5), 'corporate social disclosure' (3) and 'sustainability reporting' (3).

On the other hand, other subjects that were frequently studied together with CSRD are performance. CSRD researchers refer performance as 'firm performance' (1), 'profitability (4), 'financial performance' (4) and 'cost of capital' (2).

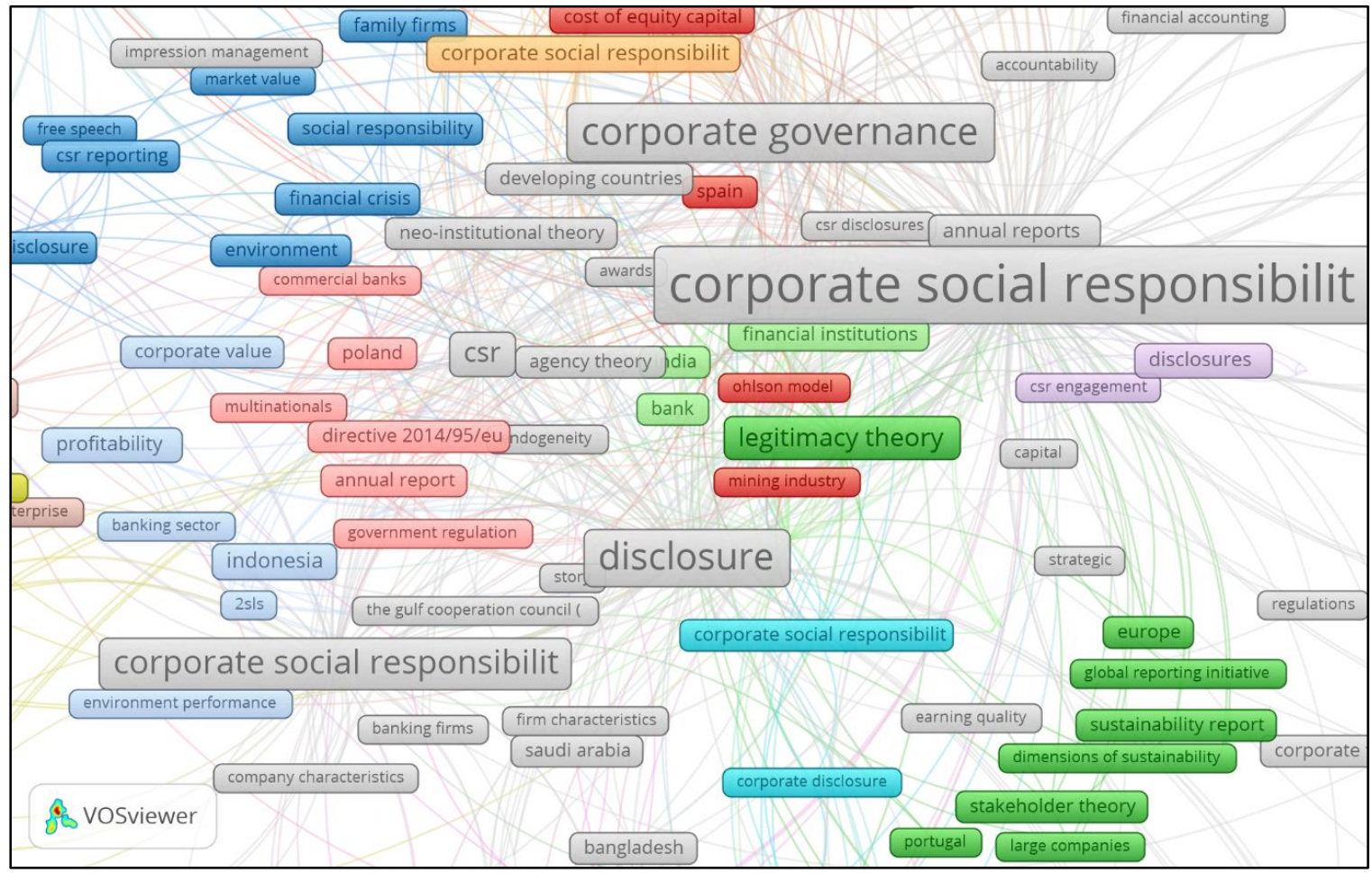

Figure 4

\section{Determinants in CSRD}

Previous studies have found that company CSR activities are depending on nature of industries and time (Gray et al., 2001; Hackston and Milne, 1996). Previous studies also have proved that the level of CSRD is determined by company willingness to disclose such 
information and also industries where they operate which this may influence company performance (Cormier and Magnan, 2003; Cormier et al., 2005).

\section{Company Size}

Watts and Zimmerman (1996) pointed out that multinational companies are more expose to public scandals. Study content that multinational is more significant in the market, possesses higher market share and attracts more audience in general. Multinational company is likely to attract more public attention, entertain a customer complaint, deal with problematic employees and subject to regulatory attention. Decision taking by multinational company arguably have a significant effect on society as the major stakeholders for the company (Knox et al., 2006). Therefore, voluntary disclosures can be meant as the tool to support regulation and improve political cost. Study by (Cullen and Christopher, 2002; Hamid, 2004; Haniffa and Cooke, 2005) agreed that CSRD were positive influence by company size and political stability.

Previous studies result also agreed that CSRD were positively influenced by the company size and sturdy political condition (Cullen and Christopher, 2002; Hamid, 2004; Haniffa and Cooke, 2005).

\section{Profitability}

Belkaoui and Karpik (1989) argued that superior management skill is the main factor who contributes to a positive relation between social disclosure and company positive performance. Management who intends to enhance their company performance will acknowledge company social responsibility as a performance tool which leads to higher social disclosure practices (Reverte, 2009). From agency and political theory perspectives, management of profitable company tends to disclose extra information to secure their position and remuneration (Giner, 1997). Practice of social voluntary disclosure by high performance company is seen as mitigating tools to reduce litigation issues due to significant attention by the public (Reverte, 2009). However, it is to note that, company performance may neither affect company social disclosure (Neu et al., 1998). Previous study stated that, as the company begins to experience with high profit, stakeholders will ensure the profit gained may not liable by higher environmental expenditure. While during the detrimental time, social disclosure by the company may act as the motivator tool to convince stakeholder that the company environmental investment will convert to long term competitive advantages (Reverte, 2009).

\section{International Listing}

It is also documented that, company who listed in foreign market much prefers to disclose more information as the company need to comply with the market rule and their listing status may attract a lot of public attention. In this sense, social disclosure practices may reduce the agency cost due to large shareholders. Align with the arguments, previous studies found that companies with international listing status significantly influence their social disclosure (Singhvi and Desai, 1971; Cooke, 1989).

\section{Leverage}

Agency theory explained that, company with higher leverage usually tends to disclose extra social information to improve their agency cost and cost of capital (Jensen and Meckling, 1976). Conversely, it is found that managers in lower leverage company will contain less 
pressure in their social activities and this may positively impact their company performance. Purushothman et al. (2000) stated that, higher level leverage company will act as the medium to convey extra social information which will positively impact the company-creditors relationship.

\section{Distribution of CSRD Publications}

Based on the analysis of CSRD articles and occurrences of authors keywords, it was suggested that there was a positive relation between the sub-related theme and main theme search. Analysis on Figure 5 showed that 'corporate governance' is the most popular sub-related theme related to CSRD with 54 scopus articles and 34 occurrences in VOSviewer. Next, 'Voluntary Disclosure' is another popular sub-topic who frequently associated by CSRD researcher with 20 articles and 5 occurrences. 'Information Disclosure' is another CSRD subrelated topic which has received significant attention recently due to the global environment and social issues with 82 articles available and 2 occurrences.

In addition, one can determine potential research area by observing the association link between the two key occurrences. To take an example, based on map 'corporate social responsibility disclosure' had been linked with another 35 keywords ( 35 links). Among related keywords are 'audit committee', 'performance', 'information disclosure', 'earnings management', 'leverage' and 'family firms'. Analysis on the map showed that research on audit committee and CSRD is least favourable than SCSRD and performance (4 links vs 6 links).

Based on the analysis of CSRD sub-related theme (corporate governance, voluntary disclosure and information disclosure), this study found that, most of the publications were coming from the United Kingdom, China and Malaysia (refer to figure 5). Whiles countries like USA, Spain, Indonesia, Australia also listed as one of the contributors in CSRD sub-related publications, with contributions of 1 .

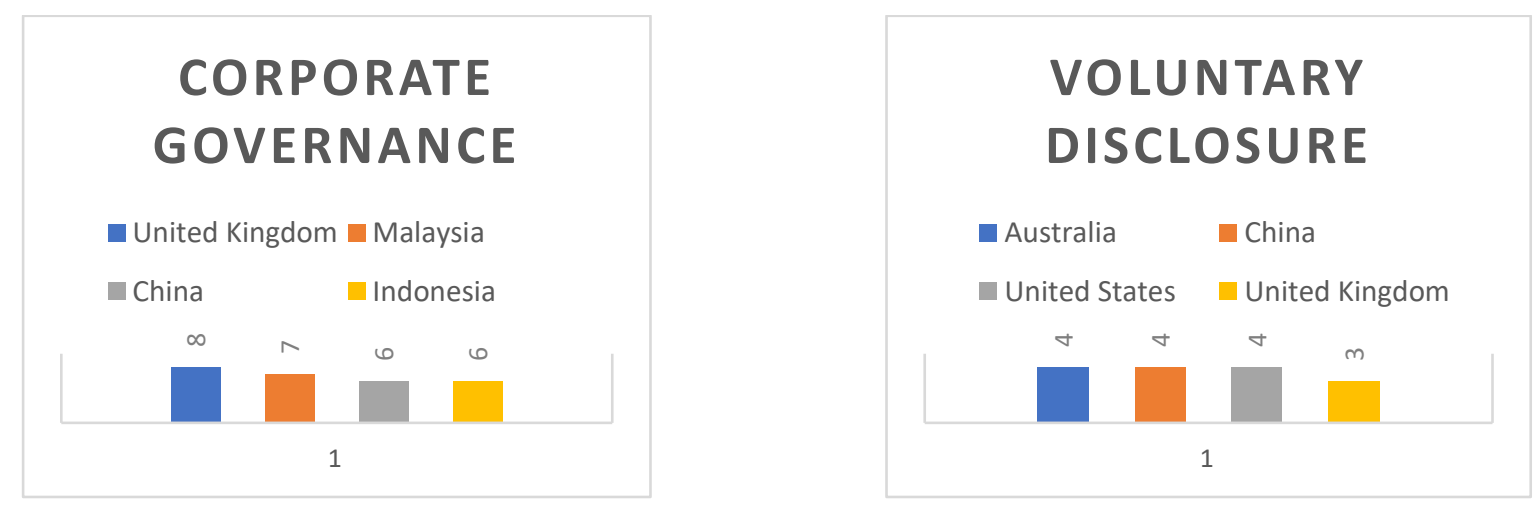

\section{INFORMATION DISCLOSURE}

united Kingdom $\square$ China

- Malaysia $\quad$ Spain

$\neg \infty \quad \infty$

1

Figure 5 


\section{Study Constraints}

This study found that by limiting the search criteria to "* corporate *social *responsibility *disclosure" in the article's topic and abstract, the search outcome may not be comprehensive cover all CSRD articles in the Scopus. This may happen as the researchers try to differentiate the term employed by using a different word such as social disclosure, environmental disclosure and CSR disclosure. In addition, analysis of co-occurrences in VOSviewer is not covering all the databases such WOS, Science Direct, and JStor which limiting the generalisation of result.

Future studies may want to look further on the analysis of CSRD publications by including multiple databases analysis such as WoS and Science Direct. This arguably will give a comprehensive analysis of CSRD publications from other search engines. WoS as an example already include a feature of 'hot paper' in their search engine to facilitate the users to identify the most cited articles in WoS. This features specifically will assist the users to identify recently published articles which receive a significant amount of citations. Therefore, by including multiple databases in bibliometric analysis may enhance the degree accuracy of analysis.

\section{Conclusions of The Study}

This study in general has provided publication trend of CSRD research by using 181 articles that were extracted from the Scopus Database. For the past 6 years, the researchers discovered that the CSRD publication is increasing which indicated that the topic is getting more attention than before. The study also found that UK, Australia and Hong Kong have the least SCP (single-country publications) which indicated that they have strong collaboration with foreign researchers. These have opened an opportunity for researchers in other countries such as Tunisia, Spain and Green to collaborate and enhance their publication output. By referring to VOSviewer map, one can determine the under-research area such as institutional ownership, managerial ownership, profitability and leverage. This can be identified by observing the colour of the link which connecting the keywords. Statedly, the identified sub-related topic can be proposed as a potential research topic in the future. Current CSRD researchers are advice to focus on another potential area related to CSRD such as Islamic finance as the importance to oblige with CSR disclosure activities is getting significant.

\section{Reference}

Belkaoui, A., \& Karpik, P. G.(1989). Determinants of the corporate decision to disclose social Information. Accounting, Auditing and Accountability Journal, 2(1), 36-51.

Brammer, S., \& Pavelin, S. (2008). Factors influencing the quality of corporate environmental disclosure. Business Strategy and the Environment, 17, 120-136.

Brown, N., \& Deegan, C. (1998). The public disclosure of environmental performance information - A dual test of media agenda setting theory and legitimacy theory. Accounting and Business Research.

Cooke, T. E. (1989). Voluntary Corporate Disclosure by Swedish Companies, Journal of International Financial Management and Accounting 1(2), 171-195.

Cormier, D., \& Magnan, M. (2003). Environmental reporting management: a continental European perspective. Journal of Accounting and Public Policy, 22(1), 43-62. 
Cullen, L., \& Christopher, T. (2002). Governance disclosures and firm characteristics of listed Australian mining companies. International Journal of Business Studies, 10(1), 37-58.

Deegan, C., \& Gordon, B. (1996). A study of the environmental disclosure practices of Australian corporations. Accounting and Business Research, 26(3), 187-199.

Deegan, C., \& Gordon, B. (1996). A study of the environmental disclosure practices of Australian corporations. Accounting and Business Research, 26(3), 187-199.

Evans, J. H. III., \& Sridhar, S. S. (2002). Disclosure disciplining mechanisms: capital markets, product markets and shareholder litigation. Accounting Review, 77(3), 595-626.

Giner, B. (1997). The influence of company characteristics and accounting regulation on information disclosed by Spanish firms. European Accounting Review, 6(1), 45-68.

Gray, R., Javad, M., Power, D. M., \& Sinclair, C. D. (2001). Social and environmental disclosure and corporate characteristics: A research note and extension. Journal of Business Finance and Accounting, 28(3), 327-356.

Gray, R., Kouhy, R., \& Lavers, S. (1995). Corporate social and environmental reporting: a review of the literature and a longitudinal study of UK disclosure. Accounting, Auditing, and Accountability journal, 8(2), 47-77.

Hackston, D., \& Milne, M. J. (1996). Some determinants of social and environmental disclosures in New Zealand companies. Accounting, Auditing and Accountability Journal, 9(1), 77-108.

Hamid, F. Z. A. (2004). Corporate Social Disclosure by Banks and Finance Companies: Malaysian Evidence. Corporate Ownership \& Control 1(4), 118-130.

Haniffa, R. M., \& Cooke, T. E. (2005). The impact of culture and governance on corporate social reporting, Journal of Accounting and Public Policy, 24(5), 391-430.

Hooghiemstra, R. (2000). Corporate communication and impression management: new perspectives why companies engage in corporate social reporting. Journal of Business Ethics, 27(1/2), 55-68.

Hutton, A. P., Miller, G. S., \& Skinner, D. J. (2003). The role of supplementary statements with manage- ment forecasts. Journal of Accounting Research, 41(5), 867-890.

Jensen, M., \& Meckling, W. (1976). Theory of the firm: Managerial behavior, agency costs and ownership structure. Journal of Financial Economics, 3, 305-360.

Khudzari, J. M., Kurian, J., Tartakovsky, B., \& Raghavan, G. V. (2018). Bibliometric analysis of global research trends on microbial fuel cells using Scopus database. Biochemical engineering journal, 136, 51-60.

Patten, D. M. (2002). The relation between environmental performance and environmental disclosure: a research note. Accounting, Organizations and Society, 27(8), 763-764.

Patten. (2002). Give or Take on the Internet: An Examination of the Disclosure Practices of Insurance Firm Web Innovators. Journal of Business Ethics, 36(3): 247-259.

Reverte, C. (2009). Determinants of corporate social responsibility disclosure ratings by Spanish listed firms, Journal of Business Ethics, 88(2), 351-366.

Sinclair-Desgagne, B., \& Gozlan, E. (2003). A theory of environmental risk disclosure. Journal of Environmental Economics and Management, 45(2), 377-393.

Singhvi, S. S., \& Desai, H. B. (1971). An empirical analysis of the quality of corporate financial disclosure. The Accounting Review, 46(1), 129-138.

Ullmann, A. E. (1985). Data in search of a theory: a critical examination of the relationships among social performance, social disclosure and economic performance of US firms'. Academy of Management Review. 
Watts, R. L., \& Zimmerman, J. L. (1986). Positive Accounting Theory (Prentice-Hall, Englewood Cliffs, NJ).

Willis, A. (2003). 'The role of the Global Reporting Initiative's Sustainability Reporting Guidelines in the social screening of investments. Journal of Business Ethics, 43(3), 233237. 